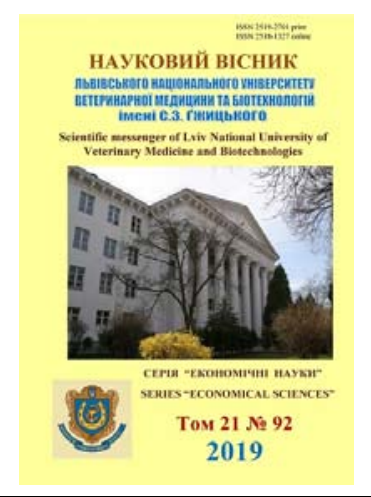

Науковий вісник Дьвівського національного університету
ветеринарної медицини та біотехнологій імені С.3. Гжицького. Серія: Економічні науки

\author{
Scientific Messenger of Lviv National University \\ of Veterinary Medicine and Biotechnologies. \\ Series: Economical Sciences
}

\title{
Functional development of rural areas of the Carpathian region in the context of ensuring the effectiveness of decentralization of power
}

\author{
G. Sedilo, N. Kotko \\ Institute of Agriculture of Carpathian region NAAS, v. Obroshyno, Ukraine
}

Article info

Received 04.02.2019

Received in revised form 05.03 .2019

Accepted 06.03.2019

Institute of Agriculture of Carpathian region NAAS, Hrushevskyi Str., 5, v. Obroshyno, 81115, Ukraine.

Tel.: +38-067-471-01-02 +38-096-136-39-98

E-mail:inagrokarpat@gmail.com nataliakotko@ukr.net

Sedilo G., \& Kotko, N. (2019). Functional development of rural areas of the Carpathian region in the context of ensuring the effectiveness of decentralization of power. Scientific Messenger of Lviv National University of Veterinary Medicine and Biotechnologies. Series: Economical Sciences, 21(92), 101-103. doi: 10.32718/nvlvet-e9216

Rural areas play a significant role in the development of the economic complex of the state. Ensuring its dynamics is especially important for the regions, which are noted by the agricultural production profile, the Carpathian region in particular. Since a nature of functioning of rural areas is manifested through functions they perform, efficiency of realization of some of these functions mainly depends on conceptual models of territorial development practiced in the state and on a role, played by its basic branch in econom$i c s$ - the agriculture. In the article problematic aspects have been systematized and analyzed, based on existing agrocentric approach to development of rural areas of Carpathian region, in the organizational, industrial-economic, financial-economic and social-economic dimensions, as well as defined promising directions of ensuring increase in their functionality in context of decentralization of power. Structural changes that took place in development of the agricultural segment of Carpathian region during the period of reforms had some ambiguous character and defined mostly destructive impact on functions realization intrinsic to rural areas. Although, on the one hand, during the last years capitalization of the agricultural production took place on the large scale, due to engagement of financial-production capital and was formed high-tech corporate brunch management segment, on the other hand, significant industry distortions, deepening deformation of rural labor market, degradation of the social sphere and rural settlement network in general still remain. Increasing functionality of rural areas anticipates, on the one hand, expanding spectrum of the functions performed by a rural settlement, and, on the other hand, ensuring diversification of rural area development. Dynamics of the referenced processes is defined by success of institution of efficient economic mechanism, which will provide reorientation to benefit subjects of rural economy of distributive relations activity in the industrial, food and financial links of the chain of added value formation, created by those subjects. One of the most important, and at the same time, the most difficult tasks of the government decentralization politics, is seen in a clear definition and differentiation of the spheres of influence and responsibility of all stakeholders in the development of rural areas: rural communities, agribusiness and rural entrepreneurs, the state, and the scientific sphere.

Key words: rural communities, agricultural production, territorial development models, stake holders of rural development, administrative and territorial reform.

\section{Функціональність розвитку сільських територій Карпатського регіону в контексті забезпечення результативності процесів децентралізації влади}

Г.М. Седіло, Н.М. Котько

Інститут сільського господарства Карпатського регіону Украӥни НААН, с. Оброшине, Украӥна

Сільські території відіграють вагому роль в розвитку господарського комплексу держави. Забезпечення його динаміки $\epsilon$ особливо важливим для регіонів, які характеризуються аграрним виробничим профілем, зокрема - Карпатського. Оскільки характер функціонування сільських територій виявляється через виконувані ними функції, ефективність реалізацї тих чи інших з них 
істотно залежить від практикованих у державі кониептуальних моделей територіального розвитку та ролі, яку відіграє у економіці базова галузь - сільське господарство. У статті систематизовано і проаналізовано в організаційній, виробничогосподарській, фінансово-економічній та соияіально-економічній площчинах проблемні, за існуючого агроцентричного підходу розвитку сільських територій Карпатського регіону, аспекти та визначено перспективні напрями забезпечення зростання їх функціональності в контексті здійснення децентралізації влади. Структурні зміни, шчо відбулись у розвитку аграрного сектора Карпатського регіону упродовж реформеного періоду носили доволі неоднозначний характер та обумовлювали переважно деструктивний вплив на реалізацію функиій, притаманних сільським територіям. Так, з одного боку, протягом останніх років завдяки залученню фінансово-промислового капіталу відбулася масштабна капіталізація сільськогосподарського виробництва, сформовано високотехнологічний корпоративний сегмент ведення галузей, з іншого - продовжують зберігатись істотні галузеві перекоси та поглиблення деформації сільського ринку праці, деградації сочіальної сфери та сільської поселенської мережі загалом. Зростання функціональності сільських територій передбачає, з одного боку, розширення спектру виконуваних селом функиій, з іншого - забезпечення диверсифікаиї̈ розвитку сільської місцевості. Динаміка означених прочесів обумовлюється успішністю налагодження ефективного господарського механізму, який забезпечуватиме переорієнтацію на користь суб'єктів діяльності сільської економіки розподільчих відносин у виробничих, продуктових і фінансових ланках ланцюга створюваної ними (суб'єктами) доданої вартості. Одне із найважливіших $i$, водночас, найскладніших завдань політики децентралізачії влади вбачається в чіткому визначенні й розмежуванні сфер впливу та відповідальності всіх стейкхолдерів розвитку сільських територій: сільських громад, агробізнесу та сільських підприємиів, держави, наукової сфери.

Ключові слова: сільські громади, сільськогосподарське виробництво, територіальні моделі розвитку, стейкхолдери сільського розвитку, адміністративно-територіальна реформа.

\section{Ветуп}

Організаційно-виробнича, соціальна і фінансова складові успішності децентралізації влади й формування дієздатних сільських громад можуть бути забезпечені лише завдяки багатофункціональному розвитку сільських територій і диверсифікації місцевої економіки, за яких поступ базових сільськогосподарських галузей стає чинником розгортання ведення неаграрних видів діяльності. Досягнення динаміки означених процесів особливо істотно для Карпатського регіону, де проживає в середньому кожний 4-й $(25,1 \%)$ економічно неактивний сільський мешканець держави, та кожний 5-й (18,3\%) - сільський безробітний; в особистих селянських господарствах, як єдиній сфері прикладання праці, зайнято в середньому 59,6\% економічно активного населення (Ofitsiinyi sait Derzhavnoi sluzhby statystyky Ukrainy).

\section{Матеріал і методи досліджень}

Всупереч декларованому курсу на євроінтеграцію та застереженням науковців щодо необхідності формування соціально орієнтованої парадигми (Borodina et al., 2012) і селозберігаючих засад розвитку (Hadzalo \& Zhuk, 2015), наразі сільські території продовжують функціонувати в парадигмі переважного домінування агровиробничої монофункціональної моделі. Зміна їі формату в напрямі залучення до потреб сільського розвитку землересурсної, виробничої, соціальної складових його потенціалу набуває особливого значення в контексті активізації самоврядування територіальних громад (Borodina et al., 2015; Novikov, 2016; Zayats', 2017; Kolomiyets' \& Pelekhatyy, 2017). Мета статті: проведення аналізу проблемних аспектів та визначення перспективних напрямів забезпечення зростання функціональності сільських територій Карпатського регіону в контексті здійснення децентралізації влади.

\section{Результати та їх обговорення}

Сільські території та сільське господарство, як базова галузь їх економіки, відіграють вагому роль в розвитку господарського комплексу держави та регіонів. Динамічний і ефективний розвиток сільських територій i, загалом, аграрної сфери є особливо важливим для регіонів, що характеризуються порівняно вищою питомою вагою створеної сільським, лісовим і рибним господарством валової доданої вартості у загальній валовій доданій вартості всіх видів економічної діяльності, зокрема - Карпатського, даний показник в якому становить $16,7 \%$, тоді як у середньому по Україні - 13,8\% (Ofitsiinyi sait Derzhavnoi sluzhby statystyky Ukrainy).

Характер розвитку сільських територій та їх реальна роль у економіці держави виявляються через функції. Їх суть полягає в основних напрямах життедіяльності, в яких виявляються виконувані ними місії та завдання. Зростання функціональності сільських територій передбачає, 3 одного боку, розширення спектру виконуваних селом функцій, 3 іншого - забезпечення диверсифікації розвитку сільської місцевості (Niedzielski, 2015).

Проблемні напрями забезпечення функціональності сільських територій Карпатського регіону за існуючого агроцентричного підходу їх розвитку нами систематизовано і проаналізовано в наступних площинах: організаційній, виробничо-господарській, фінансовоекономічній та соціально-економічній. У організаційній площині найбільш істотний вплив на характер i перспективу реалізації базових функцій сільських територій має масштабна консолідація земельних масивів і капіталізація сільськогосподарського виробництва та поглинання агрохолдинговими структурами середніх та дрібних агро формувань. Наслідком означених процесів стає звуження конкуренції на ринку сільськогосподарської продукції та обмеження можливостей впливу на розвиток сільського господарства регіональних та місцевих органів влади.

У виробничо-господарській площині найбільш впливовими чинниками, які визначають рівень функціональності сільських територій є: згортання трудомістких галузей сільськогосподарського виробництва; зміцнення монопольного контролю над формуванням продовольчих маркетингових ланцюгів з боку інтегрованих структур; незатребуваність переробною сферою сільськогосподарської продукції, вирощеної в 
особистих селянських господарства; посилення натуралізації ОСГ. Унаслідок їх впливу відбувається поглиблення структурно-галузевої деформації; посилення продуктової незбалансованості агропродовольчої сфери, обмеження доступу на ринок дрібних сільськогосподарських товаровиробників.

До найбільш істотних фінансово-економічних аспектів обговорюваної проблеми належать: “оптимізація” частки соціальних статей витрат у структурі собівартості сільськогосподарської продукції; відволікання бюджетних коштів на державну підтримку економічно самодостатніх господарських структур. Зазначені процеси і явища обумовлюють: вимивання коштів із сільських територій; звуження фінансової бази для наповнення сільських бюджетів; перекладання на державу тягаря витрат із усунення соціальних та екологічних наслідків; розпорошування бюджетних коштів на фрагментарний “точковий” вплив.

У соціально-економічній площині відбувається зростання рівня безробіття сільського населення, деградація соціального капіталу села, зменшення до критичної межі рівня та якості життя сільського населення. Результативним ефектом впливу зазначених чинників $\epsilon$ : деградація соціальної інфраструктури села; демографічна і поселенська криза на відносно периферійних територіях; наростання деструктивних соціальних настроїв на селі.

Ключові напрями забезпечення багатофункціонального характеру розвитку сільських територій: формування оптимальної організаційно-виробничої структури в сільському господарстві та розвиток процесів кооперації дрібнотоварних господарств; формування раціональної зонально-адаптованої галузевої структури с.-г; залучення с.-г. продукції домогосподарств до формування обсягів регіонального продовольчого ринку; зростання рівня продуктивності галузей та інноваційності виробництва; зростання доходності виробництва середніх і дрібнотоварних с.-г. товаровиробників; диверсифікація фінансових джерел розширеного відтворення в АПК; зростання інвестиційної спроможності господарських структур; зростання рівня зайнятості та доходів сільського населення; розвиток соціальної сфери; розвиток інженерної інфраструктури, транспорту і зв'язку.

Динаміка й ефективність процесу забезпечення багатофункціональності сільських територій визначальною мірою обумовлюється узгодженістю інтересів і злагодженістю взаємодії учасників системи “владасільські території - бізнес - наука”. Одним із найважливіших i, водночас, найскладніших завдань цілей політики децентралізації влади є чітке визначення й розмежування сфер впливу та відповідальності всіх стейкхолдерів розвитку сільських територій: сільських громад, агробізнесу та сільських підприємців, держави, наукової сфери. Тому ефективність функціонування об'єднаних територіальних громад, насамперед, визначатиметься: наявністю у громад реальних важелів впливу на місцевий розвиток; можливістю обмеження негативного впливу агрохолдингів; дієвістю економічної мотивованості сільськогосподарських товаровиробників; рівнем залучення господарств населення до формування товарних ресурсів продовольчого ринку.

\section{Висновки}

Ефективний розвиток сільської економіки та підвищення на цій основі рівня й якості життя місцевого населення потребує забезпечення виконання сільськими територіями усього спектру притаманних їм функцій - виробничої, демографічної, соціальнокультурної, екологічної, рекреаційної. Зростання функціональності сільських територій Карпатського регіону обумовлюється успішністю налагодження ефективного господарського механізму, який забезпечуватиме переорієнтацію на користь суб'єктів діяльності сільської економіки розподільчих відносин у виробничих, продуктових i фінансових ланках ланцюга створюваної ними (суб'єктами) доданої вартості.

Перспективи подальших досліджень пов'язуються iз необхідністю аналізу й прогнозування можливих наслідків посилення конкуренції між окремими функціями сільських територій: виробництво продовольчої та біоенергетичної сировини; розвиток рекреаційної сфери та збереження екологічної стабільності агроландшафтів; потреба забезпечення інтенсивного використання локального ресурсного потенціалу, як умови фінансової самодостатності сільських громад, та загрози сталості місцевого розвитку в майбутньому тощо.

\section{References}

Borodina, O.M., Prokopa, I.V., \& Yurchyshyn, V.V. (2012). Sotsioekonomichnyy rozvytok sil's'koho hospodarstva i sela: suchasnyy vymir K.: DU "In-t ekon. ta prohnozuv. NAN Ukrayiny” (in Ukrainian).

Borodina, O.M., Prokop, I.V., \& Popova, O.L. (2015). Polityka sil's'koho rozvytku na bazi hromad v Ukrayini: naukova dopovid'. K.: DU "In-t ekon. ta prohnozuv. NAN Ukrayiny" (in Ukrainian).

Hadzalo, Ya.M., \& Zhuk, V.M. (2015). Naukovi osnovy rozvytku ahrarnoho pidpryyemnytstva ta sil's'kykh terytoriy za selozberihayuchoyu modellyu (naukova dopovid'). K.: NNTs "IAE" (in Ukrainian).

Kolomiyets', I.F., \& Pelekhatyy, A.O. (2017). Teoretykopraktychni aspekty formuvannya ob'yednanykh terytorial'nykh hromad v Ukrayini, Ekonomika Ukrainy, 4, 46-55 (in Ukrainian).

Niedzielski, E. (2015). Functions of Rural Areas and Their Development. Problems of Agricultural Economics, 2, 84-94. doi: 10.5604/00441600.1152187.

Novikov, V.M. (2016). Instytutsional'ni mekhanizmy realizatsiyi sotsial'noho potentsialu detsentralizatsiyi. Demohrafiya ta sotsial'na ekonomika, 3(31), 48-60. doi: 10.15407/dse2016.03.070 (in Ukrainian).

Ofitsiinyi sait Derzhavnoi sluzhby statystyky Ukrainy [Internet]. Available from: http://www.ukrstat.gov.ua (in Ukrainian).

Zayats', T.A. (2017). Rozvytok sil's'kykh poselen' Ukrayiny $\mathrm{v}$ umovakh detsentralizatsiyi: mozhlyvosti ta ryzyky. Demohrafiya ta sotsial'na ekonomika, 3(31), 48-60. Available from: https://dse.org.ua/arhcive/31/4.pdf (in Ukrainian). 